\title{
Review Paper: Balance Performance Disorders and Sway of the Center of Gravity in Children With ADHD
}

\author{
Behzad Amini $^{1}$ (D), Seyed Ali Hosseini ${ }^{1,2}$, Nazila Akbarfahimi ${ }^{1 *}$ (D) \\ 1. Department of Occupational Therapy, University of Social Welfare and Rehabilitation Sciences, Tehran, Iran. \\ 2. Social Determinants of Health Research Centre, University of Social Welfare and Rehabilitation Sciences, Tehran, Iran.
}

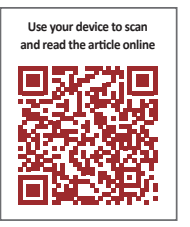

Citation: Amini B, Hosseini SA, Akbarfahimi N. Balance Performance Disorders and Sway of the Center of Gravity in Children With ADHD. Journal of Modern Rehabilitation. 2018; 12(1):3-12. http://dx.doi.org/10.32598/jmr.12.1.3

: http://dx.doi.org/10.32598/jmr.12.1.3

Funding: See Page 10

(c) Copyright: The Author(s)

Article info:

Received: 10 Apr 2017

Accepted: 20 Sep 2017

Available Online: 01 Jan 2018

\section{Keywords:}

Sway, Balance, ADHD, Motor deficit

\begin{abstract}
Introduction: The main characteristics of Attention Deficit Hyperactivity Disorder (ADHD) are the emergence of stability patterns of attention deficit, hyperactivity and impulsivity. These disorders affect the balance performance of the patients. The disorder has a relatively high prevalence in school-aged children. The purpose of this review study is to investigate the balance and postural abilities of children with ADHD.
\end{abstract}

Materials and Methods: The objectives of this study were investigated by searching in the Web of Science, Medline, PubMed and OTseeker databases. The articles with these criteria were included in this study: published articles in English and Persian accredited journals; study participants were school-aged children with ADHD; Articles with the aim of assessing the participants' balance skills, the rate of sway of the center of gravity and motor disorders in children with ADHD. The articles were published between 2002 to March 2018. Finally, 18 eligible articles were met the inclusion criteria and reviewed.

Results: The 18 articles were entered to the study. The results of most of the articles show disturbances in the balance and Sway of ADHD's children's center of gravity. Balance and motor disorder in children with $\mathrm{ADHD}$ has a very high prevalence.

Conclusion: The simultaneity of this disorder with DCD and the presence of some defects in the performance of cerebellar in these children are evident and confirms the presence of balance and motor control disorders in children with ADHD. The reason for the defects in the performance of some brain parts is not clear yet.

\section{Introduction}

A ttention Deficit Hyperactivity Disorder (ADHD) is a neurodevelopmental disorder in which the individual represents stability patterns of attention deficit, hy- peractivity and impulsivity. The prevalence of ADHD has been reported to be $9.5 \%$ to $11.4 \%$ in school-aged children [1]. The prevalence rate differs in different ages and is $11.4 \%$ in ages from $6-12$ years, $5 \%$ in $13-18$ years but decreases from 19 years to adolescence [1].

* Corresponding Author: 
Children with ADHD definitely encounter with some problems in their daily activities $[1,2]$ and also school activities [1]. In particular, they are mostly excommunicated by peers and have lower self-esteem [1]. Children with ADHD represent specific symptoms of hyperactivity such as excessive running and jumping, restlessness, hate permanent situations, not tolerating waiting and conformity, and impulsive movements without predicting outcomes [1].

There are several hypothesis to analyze the causes of ADHD. Structural differences have been observed in the brain of children with ADHD. The frontostriatal, tempoparietal lobes, basal ganglia, corpus callosum, cerebellum, thalamus and amygdala areas are included. There are findings indicating the decrease of gray matter in the right side of prefrontal area in elder children with ADHD that can be associated with the weakness of these children in controlling their motor behavior $[2,3]$.

Likewise, it was mentioned that cerebellum, caudate nucleus, and prefrontal cortex areas are matured later [1]. These areas play an important role in attention, thought, and motor planning [1]. Other hypotheses blame defects in some neurotransmitters for the symptoms of ADHD $[2,4]$. In these children, the level of dopamine and norepinephrine seems to be lower. Some drugs like methylphenidate [5] increase the level of dopamine in the prefrontal area $[1,6]$.

Children with ADHD often have comorbidity with psychiatric disorders such as autism spectrum disorder or tic and also neurodevelopmental disorders like dyslexia or Developmental Coordination Disorder (DCD) [7]. It is mentioned that more than $50 \%$ of children with ADHD have DCD, and also more than half of the children with DCD have criteria of ADHD [7]. This disorder is intervening with the educational development and the daily activities of the child [7]. Even children with ADHD who do not have DCD criteria show weaker motor performance compared to normal children [1].

Nearly half of the children with ADHD disorder also experience a wide range of motor disorders including gross and fine motor control problems [8] and problems related to maintaining balance and motor coordination [9]. Many aspects of these motor disorders such as timing, coordination, and amount of force [10] depend on the performance of the cerebellum [11]. Studies indicate a relation between motor patterns and symptoms of ADHD disorder [2]. Motor and balance disorders in children with ADHD associates more with attention deficit of these children than their hyperactivity and impulsivity symptoms [10].

Balance control requires the integration of somatosensory, vestibular and visual information, and this integration is accomplished by the cerebellum, which is known as a key processor [10]. Higher balance control needs attention and processing of the central information. Therefore, more than one subcortical net mechanism is strongly related to the cognitive process [10]. In a study, greater degree of sway of the center of gravity in children with ADHD was recorded when performing cognitive activities of auditory memory [12]. Two main methods to diagnose the balance performance are measuring the Center of Pressure (COP) displacement and Sensory Organization Test (SOT) [10]. The purpose of this study is to classify and integrate the results of studies in this field.

\section{Materials and Methods}

In March 2018, the initial review was conducted on the Web of Science, Medline, PubMed and Otseeker search engines. The first search was conducted with this words combination: balance in children with ADHD. The following searches were done with balance and attention deficit, sway and ADHD, and the motor deficit in ADHD. The complementary Persian search was conducted with combinations of balance and degree of sway of the center of gravity in children with attention deficit hyperactivity disorder.

The inclusion criteria of the study were as follows: The full text of the published article in English and Persian must be in valid journals, study participants should be school-aged children with ADHD, the aim of evaluation must be balance skills, the degree of sway of the center of gravity and motor disorders in children with ADHD and objective measurements should be used. Articles must be published between 2002 and March 2018.

\section{Results}

At first, the author was responsible to investigate the inclusion criteria, and then the list of accepted and rejected articles was investigated by the other members of the expert group. In total, 68 articles related to the subject were assessed out of the preliminary results. Of these articles, 28 articles met the criteria, but after investigating the quality of articles only 18 articles were entered to the study (Figure 1). First, the articles were completely studied by the first author and the points were extracted. Afterwards, the articles were given to other authors to re- 


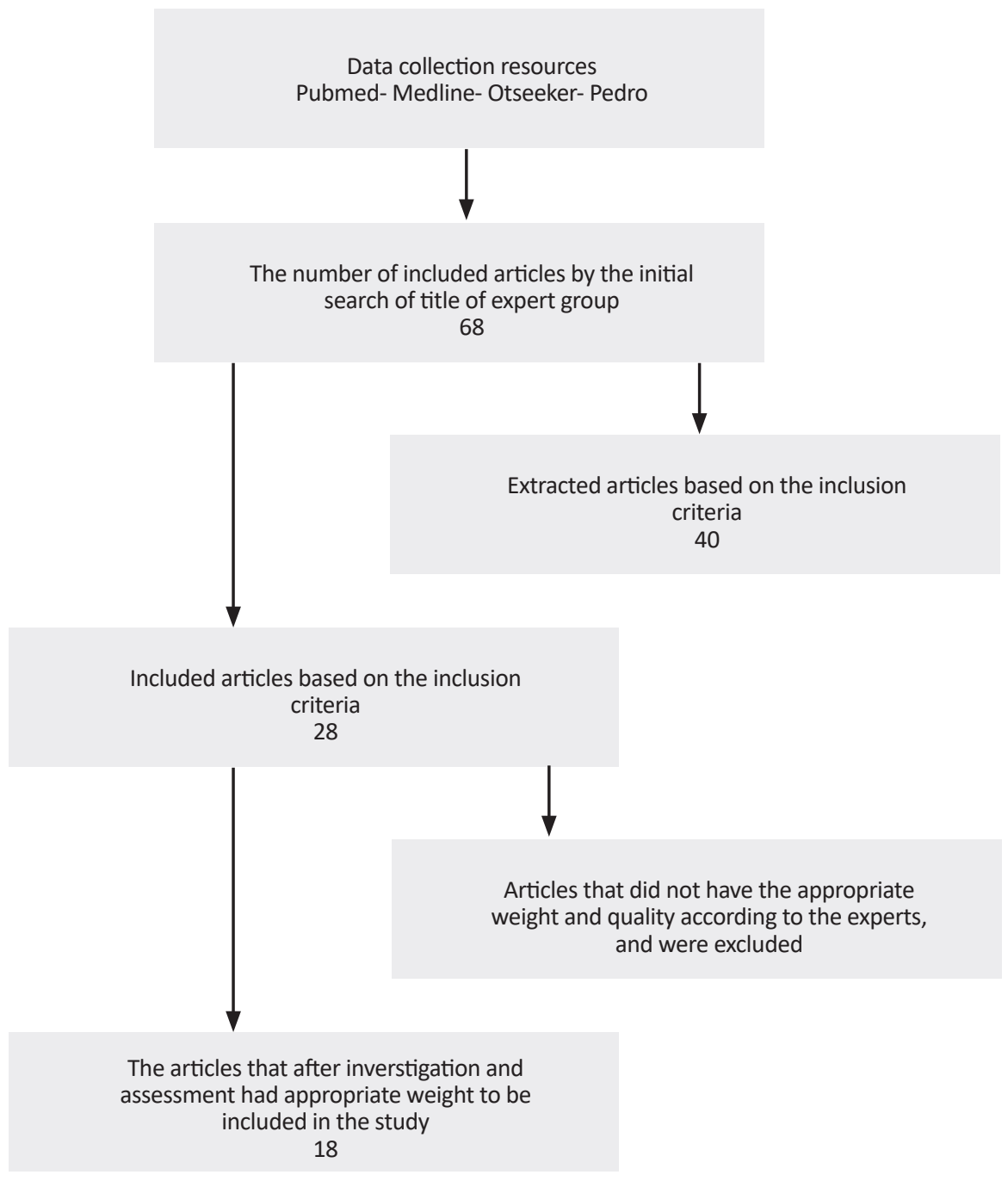

Figure 1. Diagram the process of selecting articles

view them according to their expertise and the relevant items were completed (Table 1).

\section{Discussion}

After investigating the relevant articles, the following results were obtained:

\section{Balance and ADHD symptoms}

In Goetz study conducted on 62 children with ADHD, children showed weaker performance in balance tasks. These children have more sways from the center of gravity [13]. Furthermore, falling rate of these children down the balance board is more than that of normal children [13]. The relation between balance scores and severity disorder in children with ADHD was not ob- served. However, the relationship between reaction time and balance was observed both in normal children and ADHD children [13].

Sudha et al. by studying 15 children with ADHD found that children with ADHD of severe combined type are likely to exhibit a greater degree of motor and balance disorders [14]. Both Dutra and Amini in their articles, mentioned that the way children with ADHD walk and precise analysis and recording the relevant parameters can be used for detection and classification of ADHD in the future $[2,15]$.

Kaiser et al. found that children with ADHD need more time to plan their movements and need more online control [1]. This study indicates that dynamic balance and fine motor skills are improved when children 
Table 1. Summarizes the characteristics of the studies included in this review article

\begin{tabular}{|c|c|c|c|c|c|}
\hline Title & $\begin{array}{l}\text { Writer \& Year } \\
\text { of Publication }\end{array}$ & $\begin{array}{l}\text { Study } \\
\text { Sample/ } \\
\text { Age }\end{array}$ & Variables & $\begin{array}{l}\text { Measurement } \\
\text { Tools }\end{array}$ & Main Results \\
\hline $\begin{array}{l}\text { Comparative study of mobility } \\
\text { quality and walking parameters in } \\
\text { children with ADHD and normal } \\
\text { controls [2] }\end{array}$ & $\begin{array}{l}\text { Amini B, } \\
2016\end{array}$ & $\begin{array}{l}20 \text { children } \\
\text { with ADHD } \\
5-12 \text { years }\end{array}$ & $\begin{array}{l}\text { Balance of } \\
\text { walking param- } \\
\text { eters }\end{array}$ & Balance master & $\begin{array}{l}\text { Difference in static bal- } \\
\text { ance was significant }\end{array}$ \\
\hline $\begin{array}{c}\text { The comparison of postural con- } \\
\text { trol skills under different sensory } \\
\text { conditions in DCD children and } \\
\text { normal peers [7] }\end{array}$ & $\begin{array}{l}\text { Amini B, } \\
2016\end{array}$ & $\begin{array}{l}22 \text { children } \\
\text { with DCD }\end{array}$ & Postural control & Equei test & $\begin{array}{l}\text { Comorbidity between } \\
\text { DCD and ADHD postural } \\
\text { control defect }\end{array}$ \\
\hline $\begin{array}{l}\text { Effects of distractors on upright } \\
\text { balance performance in school- } \\
\text { aged children with attention } \\
\text { deficit hyperactivity disorder, } \\
\text { preliminary study [10] }\end{array}$ & $\begin{array}{l}\text { Aydinli FE, } \\
2016\end{array}$ & $\begin{array}{l}26 \text { children } \\
\text { with ADHD } \\
7-12 \text { years }\end{array}$ & $\begin{array}{l}\text { Sensory Organi- } \\
\text { zation Test } \\
\text { (SOT) }\end{array}$ & $\begin{array}{c}\text { Dynamic posturog- } \\
\text { raphy }\end{array}$ & $\begin{array}{c}\text { Balance in children with } \\
\text { ADHD was weaker but } \\
\text { the difference was not } \\
\text { significant }\end{array}$ \\
\hline $\begin{array}{l}\text { Postural control among children } \\
\text { with and without attention deficit } \\
\text { hyperactivity disorder in single } \\
\text { and dual conditions [12] }\end{array}$ & $\begin{array}{l}\text { Shorer Z, } \\
2012\end{array}$ & $\begin{array}{l}24 \text { children } \\
\text { with ADHD } \\
\text { 9.7- } 10.7 \\
\text { years }\end{array}$ & COP test & $\begin{array}{l}\text { Kistler single force } \\
\text { platform }\end{array}$ & $\begin{array}{c}\text { Postural control was si- } \\
\text { multaneously improved } \\
\text { in accomplishment of } \\
\text { dual tasks }\end{array}$ \\
\hline $\begin{array}{l}\text { Dynamic balance in children with } \\
\text { Attention Deficit Hyperactivity } \\
\text { Disorder and its relationship with } \\
\text { cognitive functions and cerebel- } \\
\text { lum [13] }\end{array}$ & $\begin{array}{l}\text { Goetz M, } \\
2017\end{array}$ & $\begin{array}{l}62 \text { children } \\
\text { with ADHD } \\
7-11 \text { years }\end{array}$ & $\begin{array}{l}\text { Balance and } \\
\text { diagnostic } \\
\text { symptoms of } \\
\text { ADHD }\end{array}$ & $\begin{array}{l}\text { The phyaction bal- } \\
\text { ance board, Con- } \\
\text { ners' continuous } \\
\text { performance }\end{array}$ & $\begin{array}{l}\text { Balance control of } \\
\text { children with ADHD } \\
\text { was weaker and their } \\
\text { cognitive disorder was } \\
\text { related to cerebellum }\end{array}$ \\
\hline $\begin{array}{l}\text { Children with ADHD and motor } \\
\text { dysfunction compared with } \\
\text { children with ADHD only. Devel- } \\
\text { opmental medicine and child } \\
\text { neurology [14] }\end{array}$ & $\begin{array}{l}\text { Tervo RC, } \\
2002\end{array}$ & $\begin{array}{l}49 \text { children } \\
\text { with ADHD } \\
\text { and motor } \\
\text { dysfunction, } \\
44 \text { primary } \\
\text { school-aged } \\
\text { children } \\
\text { with ADHD }\end{array}$ & $\begin{array}{l}\text { Balance and } \\
\text { diagnostic } \\
\text { symptoms of } \\
\text { ADHD }\end{array}$ & $\begin{array}{l}\text { Conners' Parent } \\
\text { Rating Scale } \\
\text { Child Attention } \\
\text { Problems Rating } \\
\text { Scale }\end{array}$ & $\begin{array}{c}\text { Children with ADHD } \\
\text { and motor dysfunction } \\
\text { like children with ADHD } \\
\text { have severe balance } \\
\text { disorders }\end{array}$ \\
\hline $\begin{array}{l}\text { Gait classification for ADHD } \\
\text { children using modified dual } \\
\text { tree complex wavelet transform. } \\
\text { Computing and Communication } \\
\text { Technologies (WCCCT) [15] }\end{array}$ & $\begin{array}{l}\text { Sudha D, } \\
2017\end{array}$ & $\begin{array}{l}15 \text { children } \\
\text { with ADHD }\end{array}$ & & & $\begin{array}{l}\text { The difference between } \\
\text { ADHD and normal } \\
\text { group were found by } \\
\text { inputting the wavelets } \\
\text { into the self-organizing } \\
\text { map. The differences } \\
\text { were found between } \\
\text { each group and it } \\
\text { results that there is } \\
\text { a change in the gait } \\
\text { among ADHD and } \\
\text { normal is proved }\end{array}$ \\
\hline $\begin{array}{l}\text { Objective measurement of the } \\
\text { balance dysfunction in attention } \\
\text { deficit hyperactivity disorder chil- } \\
\text { dren. Chin J Clin Rehabil [22] }\end{array}$ & $\begin{array}{l}\text { Zang Y, } \\
2002\end{array}$ & $\begin{array}{l}38 \text { children } \\
\text { with ADHD } \\
4.7-12.5 \\
\text { years }\end{array}$ & $\begin{array}{c}\text { Balance of } \\
\text { walking param- } \\
\text { eters }\end{array}$ & Balance master & $\begin{array}{l}\text { In various sensational } \\
\text { conditions the degree } \\
\text { of the sway of the cen- } \\
\text { ter of gravity in children } \\
\text { with ADHD was more }\end{array}$ \\
\hline $\begin{array}{l}\text { Evidence of brain dysfunction in } \\
\text { attention deficit-hyperactivity } \\
\text { disorder: A controlled study with } \\
\text { proton magnetic resonance spec- } \\
\text { troscopy. Academic radiology [28] }\end{array}$ & $\begin{array}{l}\text { Fayed N, } \\
2007\end{array}$ & $\begin{array}{l}22 \text { school- } \\
\text { aged chil- } \\
\text { dren with } \\
\text { ADHD }\end{array}$ & $\begin{array}{l}\text { Performance of } \\
\text { right prefron- } \\
\text { tal and white } \\
\text { matter of the } \\
\text { brain }\end{array}$ & $\begin{array}{l}\text { Radiologic evalua- } \\
\text { tion MRI }\end{array}$ & $\begin{array}{c}\text { Disorder in the perfor- } \\
\text { mance of right prefron- } \\
\text { tal and white matter of } \\
\text { the brain }\end{array}$ \\
\hline $\begin{array}{l}\text { The effectiveness of sensory-mo- } \\
\text { tor integration with an emphasis } \\
\text { on proprioceptive and vestibular } \\
\text { senses on the symptoms of Atten- } \\
\text { tion Deficit Hyperactivity Disorder } \\
\text { (ADHD) [29] }\end{array}$ & $\begin{array}{l}\text { Ebrahimi M, } \\
2013\end{array}$ & $\begin{array}{l}16 \text { children } \\
\text { with ADHD } \\
6-12 \text { years }\end{array}$ & & $\begin{array}{l}\text { The Child Symp- } \\
\text { tom Inventory-4 } \\
\text { (CSI-4) }\end{array}$ & $\begin{array}{l}\text { Balance- sensory inte- } \\
\text { gration program helped } \\
\text { the improvement of } \\
\text { ADHD symptoms }\end{array}$ \\
\hline
\end{tabular}




\begin{tabular}{|c|c|c|c|c|c|}
\hline Title & $\begin{array}{l}\text { Writer \& Year } \\
\text { of Publication }\end{array}$ & $\begin{array}{l}\text { Study } \\
\text { Sample/ } \\
\text { Age }\end{array}$ & Variables & $\begin{array}{l}\text { Measurement } \\
\text { Tools }\end{array}$ & Main Results \\
\hline $\begin{array}{c}\text { Motor cortex excitability in Atten- } \\
\text { tion Deficit Hyperactivity Disorder } \\
\text { (ADHD): A systematic review and } \\
\text { meta-analysis. } \\
\text { Research in developmental dis- } \\
\text { abilities [30] }\end{array}$ & $\begin{array}{l}\text { Dutra T, } \\
2016\end{array}$ & & $\begin{array}{l}\text { A system- } \\
\text { atic review and } \\
\text { meta-analysis }\end{array}$ & & $\begin{array}{l}\text { On comparing subjects } \\
\text { with ADHD and con- } \\
\text { trols, the forest plot } \\
\text { profiles were similar } \\
\text { in respect to the Rest- } \\
\text { ing Motor Threshold } \\
\text { (RMT), and Silent Period } \\
\text { (SP) but a significant } \\
\text { difference was found } \\
\text { for Short Intracortical } \\
\text { Inhibition (SICI) }\end{array}$ \\
\hline $\begin{array}{l}\text { The relationship between motor } \\
\text { skills, ADHD symptoms, and child- } \\
\text { hood body weight. Research in } \\
\text { developmental disabilities [23] }\end{array}$ & $\begin{array}{l}\text { Goulardins JB, } \\
2016\end{array}$ & $\begin{array}{l}189 \text { children } \\
\text { with ADHD } \\
6-10 \text { years }\end{array}$ & Balance & $\begin{array}{l}\text { Movement Battery } \\
\text { Assessment }\end{array}$ & $\begin{array}{l}\text { Over weight and bal- } \\
\text { ance are related in } \\
\text { children with ADHD }\end{array}$ \\
\hline $\begin{array}{l}\text { Changes in gait balance and } \\
\text { brain connectivity in response } \\
\text { to equine-assisted activity and } \\
\text { training in children with attention } \\
\text { deficit hyperactivity disorder. } \\
\text { The Journal of Alternative and } \\
\text { Complementary Medicine [18] }\end{array}$ & $\begin{array}{l}\text { Hyun GJ, } \\
2016\end{array}$ & $\begin{array}{l}12 \text { school- } \\
\text { aged chil- } \\
\text { dren with } \\
\text { ADHD }\end{array}$ & $\begin{array}{l}\text { Performance } \\
\text { of brain ADHD } \\
\text { symptoms }\end{array}$ & $\begin{array}{c}\text { FMRI } \\
\text { The Korean ADHD } \\
\text { scale }\end{array}$ & $\begin{array}{l}\text { The clinical symptoms } \\
\text { of ADHD decreased us- } \\
\text { ing the simulated horse } \\
\text { riding stimulation } \\
\text { The structure of brain } \\
\text { does not change }\end{array}$ \\
\hline $\begin{array}{l}\text { Balance deficit and brain connec- } \\
\text { tivity in children with ADHD [6] }\end{array}$ & $\begin{array}{l}\text { Kim SM, } \\
2017\end{array}$ & $\begin{array}{l}13 \text { school- } \\
\text { aged chil- } \\
\text { dren with } \\
\text { ADHD }\end{array}$ & Balance & $\begin{array}{c}\text { COP } \\
\text { Plantar pressure }\end{array}$ & $\begin{array}{l}\text { Balance disorder was } \\
\text { apparent in children } \\
\text { with ADHD }\end{array}$ \\
\hline $\begin{array}{l}\text { Balance deficits and ADHD } \\
\text { symptoms in medication-naive } \\
\text { school-aged boys [24] }\end{array}$ & $\begin{array}{l}\text { Konicarova J, } \\
2014\end{array}$ & $\begin{array}{l}35 \text { boys with } \\
\text { ADHD } \\
\text { 8-11 years }\end{array}$ & $\begin{array}{l}\text { ADHD symp- } \\
\text { toms balance }\end{array}$ & $\begin{array}{l}\text { The Physical and } \\
\text { Neurological Ex- } \\
\text { amination for Soft } \\
\text { Signs scale (PAN- } \\
\text { ESS) by Denckla }\end{array}$ & $\begin{array}{l}\text { ADHD symptoms are } \\
\text { related with balance } \\
\text { deficits }\end{array}$ \\
\hline $\begin{array}{c}\text { Gait in children with Attention } \\
\text { Deficit Hyperactivity Disorder in a } \\
\text { dual-task paradigm [27] }\end{array}$ & $\begin{array}{l}\text { Manicolo O, } \\
2017\end{array}$ & $\begin{array}{l}30 \text { children } \\
\text { with ADHD } \\
7-13 \text { years }\end{array}$ & $\begin{array}{l}\text { Sway of the } \\
\text { center of } \\
\text { gravity ADHD } \\
\text { symptoms }\end{array}$ & $\begin{array}{l}\text { GAITRite record- } \\
\text { ings of spatio- } \\
\text { temporal and } \\
\text { variability gait } \\
\text { parameters }\end{array}$ & $\begin{array}{l}\text { Accomplishment of } \\
\text { dual tasks decreased } \\
\text { the sway of the center } \\
\text { of gravity in children } \\
\text { with ADHD }\end{array}$ \\
\hline $\begin{array}{c}\text { Balance in children with attention } \\
\text { deficit hyperactivity disorder } \\
\text { combined type [25] }\end{array}$ & $\begin{array}{l}\text { Mao HY, } \\
2014\end{array}$ & $\begin{array}{l}20 \text { school- } \\
\text { aged chil- } \\
\text { dren with } \\
\text { ADHD }\end{array}$ & $\begin{array}{l}\text { Static and dy- } \\
\text { namic balance }\end{array}$ & $\begin{array}{c}\text { Movement Assess- } \\
\text { ment Battery for } \\
\text { Children (MABC) } \\
\text { and the Bruininks- } \\
\text { Oseretsky Test }\end{array}$ & $\begin{array}{c}\text { The static and dynamic } \\
\text { balance ability of ADHD- } \\
\text { C is lower }\end{array}$ \\
\hline $\begin{array}{l}\text { What is the evidence of impaired } \\
\text { motor skills and motor control } \\
\text { among children with Attention } \\
\text { Deficit Hyperactivity Disorder } \\
\text { (ADHD)? Systematic review of the } \\
\text { literature [1] }\end{array}$ & $\begin{array}{l}\text { Kaiser ML, } \\
\quad 2015\end{array}$ & & $\begin{array}{l}\text { A systematic } \\
\text { review }\end{array}$ & & $\begin{array}{l}\text { More than half of the } \\
\text { children with ADHD } \\
\text { have difficulties with } \\
\text { gross and fine motor } \\
\text { skills }\end{array}$ \\
\hline
\end{tabular}

with ADHD are treated with medicine. It seems that medicine does not result in static balance. Probably because the effect of automatic processes on static balance may be much greater than dynamic balance. It should be noted that while some children exhibit recovery when using medicine, others still exhibit moderate to severe motor deficits [1]. Many studies have found that the childhood problems like learning disability, autism dyslexia and also ADHD are related to Sensory Integration
Deficit (SID). Therefore, in order to treat these disorders sensory integration treatment has been widely used [22].

According to the results of the study by Manicolo, conducted on 30 children with ADHD, balance disorders while performing dual tasks occur more in children with ADHD than normal children [26]. It is emphasized that walking needs the EF ability [27]. The prevalence 
of SID in children with ADHD varies from $40 \%$ to $84 \%$. This rate is only $16 \%$ in normal children.

The results indicate that children with ADHD who suffer from specific disorders in the degree of sway of their center of gravity under static conditions can benefit from postural exercises. Therefore, it seems that the relation between mobility and aspects of attention and hyperactivity of ADHD should be considered important from the medical prospect. The conditions of the width and length of step, speed, and symmetry in the walking of children with ADHD are not different from normal children. The degree of sway of the center of gravity in children with ADHD when standing on one leg is more than that in normal children. Children with ADHD are probably in difficulty when controlling the direction of the sway of the center of gravity [2].

It should be considered that there are also problems of motor planning, motor control and timing in children with ADHD that can negatively affect their balance and motor performance. Children with ADHD have less ability in controlling their balance on instable surfaces compared to their peers, and probably have some weaknesses in preserving balance in static positions.

\section{Brain dysfunction}

It was noteworthy that the reaction time also increased by injury to the cerebellum. Balance performance is strongly related with the performance of cerebellum in all children. Therefore, cerebellum is the central structure of regulating body balance. It is capable of integrating the information obtained from various types of sensory inputs and also has the ability to model the future mode of an object, which is necessary for preventive control [13]. Children with ADHD have significantly poor performance in dynamic balance, and this can be similar to children with cerebral damage. Therapists should pay attention to the possibility that balance disorder can be an important symptom of ADHD [13].

In Hyun study that used TMS to stimulate the brain of children with ADHD, it was found that the brain neurophysiological parameters of the children with ADHD is different with others. Despite the few studies in this field, regarding the high homogeneity of the results, and considering the high difference in volume of neurotransmitters, lower levels of cortical inhibition in children with ADHD can be observed compared to healthy children $[17,18]$.
Zang (2002) by studying 38 children with ADHD, reported that clinical symptoms and balance of walking in children with ADHD improved after four weeks of horse riding program. Moreover, functional connections increased between the cerebellum and the frontal cortex. Of course, horse riding can also be effective in reducing the clinical symptoms which indicates the relation between clinical symptoms and motor and balance symptoms [22].

According to the study by Gulardins conducted on 189 children, balance disorder in children with ADHD is probably due to the disorder in sensory input, the integration of senses, or inhibition of additional movements. Probably hyperactivity can cause disorder in static balance of these children [22]. Moreover, regarding the relation between balance disorders and overweight of children, ADHD is more observed in these children [23]. According to the study by Amini, the severity of ADHD symptoms is related to body imbalance [6]. In Konicarova study on 35 boys with ADHD, the results indicate that balance disorders while performing tasks with closed eyes was greater in children with ADHD than normal children, and these disorders are related to prefrontal areas that are responsible for executive functions and the cerebellum [24].

In 2007, Fayed investigated the brain performance of the children with ADHD. In the taken neurology images, the changes in volume and poor performance of basal ganglia and the small size of the cerebellum were observed in children with ADHD. In fact, these two organs have important role in movement control and balance. Moreover, basal ganglia plays an important role in postural control and coordination of posture and movement [28]. Ebrahimi, based on the results of his study on 16 children with ADHD, concluded that the negative effects of sensory integration disorders on the balance-motor patterns of these children should be considered [29].

Regarding that the cerebellum is the central structure of regulating the body balance, and balance is associated with the reaction speed, and taking into account the several studies that indicate cerebral injury both by imaging and in performance of children with ADHD, the existence and the relation between these three issues (cerebellum, balance, reaction speed) can be confirmed $[2,28,30]$. Moreover, because the cerebellum is one of the main structures in the process of sensory integration, disorders of sensory integration in these children should not be overlooked [7] and motor symptoms due to lack of sensory integration can be observed in children with ADHD [7]. In addition to the cerebellum, caudate nucle- 
us and prefrontal cortex are matured later. Regarding that these areas play an important role in attention, thought and motor planning, they can be the possible causes of motor weaknesses in children with ADHD, and also decrease in the volume of the basal ganglia [3].

Balance in the subcategories and comorbidity with other disorders

In general, children with type A of ADHD (children with ADHD whose main problem is attention deficit) and type $\mathrm{C}$ (children with ADHD exhibiting both attention deficit and hyperactivity of symptoms) show more motor disorders. If these symptoms accompany DCD symptoms, will usually remain fixed like the main symptoms in childhood and primary school age [16]. If symptoms of ADHD and DCD are developed together, probably they have common etiology. These two disorders in some common areas of the brain such as amygdala, insular cortices, putamen, angular gyrus, right supra marginal gyrus, bilateral inferior frontal gyri, indicate pallidum.

Comorbidity can be the reason for lack of motor skills among children with ADHD [19]. The most common accompanying reported disorder is DCD and then autism that both of them can affect the motor abilities of these children. Mao based on his study reported that children with ADHD type $\mathrm{C}$ exhibited more instability than normal children when posited on a mechanical horse. These children presumably have problems in finding appropriate concordant strategies, therefore they permanently change their own movement patterns to control their balance. Considering the important role of the cerebellum in movement timing and error correction, the weakness in these children is understandable [25].

Although the relation between the subgroups of ADHD and motor problems is still unknown, maximum disorder in A and $\mathrm{C}$ groups have been reported. Probably, disorder in the sensory integration in these children is also effective in reducing the balance control ability and the degree of sway of the center of gravity [1]. Similar functional conflicts and disorders in some areas of the brain such as the cerebellum in ADHD and DCD disorders can indicate common etiology in these two disorders, although further studies are required. There are three main hypotheses to explain the motor problems related to ADHD. First, comorbidity can be the reason for lack of motor skills among children with ADHD [19]. The most common accompanying reported disorder is DCD and then autism that both of them can affect the motor abilities of these children.
The second hypothesis is that deficit in motor skills is due to lack of attention. The fact that children with ADHD perform more and better in dual task conditions and balance performance than others, led to this conclusion that dual tasks, that affects the performance, increases the level of consciousness. The consciousness level of children with ADHD may fluctuate in single tasks and cause more changes in the performance level, while the consciousness level is more stable in dual tasks.

Lack of inhibition prevents the motor control [20]. This capacity affects executive functions such as working memory, affective self-regulation, motivation, arousal, internalization of speech, and reconstruction. Then, disorders in these executive functions interferes the ability of motor control [21]. With this viewpoint, studies have indicated that lack of inhibition is one of the main features of children with ADHD [1].

Balance deficit relates to ADHD symptoms, which reflects brain disorders related to higher level of cognitive, motor, and vestibular integration. However, it is unclear whether the disorder is more in the dynamic balance or the static balance. The effect of common ADHD medicine treatment on the balance ability of these children still needs further investigation.

Preliminary evidence suggests a disorder in the balance of children with ADHD that is not due to the side effects of drug and other neurological disorders. Also, the existence of disorders in cerebellar functions and its relation with the poor balance performance of children with ADHD seem clear. Regarding the above mentioned issues, it may be possible to use the analysis of motor and balance patterns of children with ADHD for diagnosis, assessment, and treatment. Perhaps the balance disorder can be more seriously considered in assessing and rehabilitation of these children. More studies are required to evaluate the effectiveness of using balance stimulations and use of dual motor-cognitive tasks. Using precise balance assessments to assist the diagnostic process in children with ADHD needs further studies considering the type of ADHD, age, and sex of the patients.

\section{Ethical Considerations}

\section{Compliance with ethical guidelines}

According to the type of study, Ethical guidelines are followed. 


\section{Funding}

This study was conducted as part of the MSc. thesis of the first author in the Department of Occupational Therapy, University of Social Welfare and Rehabilitation Sciences, Tehran, Iran.

\section{Conflict of interest}

The authors declare no conflict of interest.

\section{Acknowledgements}

We appreciate the authors of all the articles we reviewed in this study.

\section{References}

[1] Kaiser ML, Schoemaker M, Albaret JM, Geuze R. What is the evidence of impaired motor skills and motor control among children with Attention Deficit Hyperactivity Disorder (ADHD)? Systematic review of the literature. Research in Developmental Disabilities. 2015; 36:338-57. [DOI:10.1016/j. ridd.2014.09.023] [PMID]

[2] Amini B, Hosseini SA, Biglarian A, Amiri N, Pishyareh E. Comparative study of mobility quality and walking parameters in children with ADHD and normal controls. Journal of Biomedical Science. 2016; 1(3):e8105. [DOI:10.17795/jmb-8105]

[3] Seidman LJ, Valera EM, Makris N. Structural brain imaging of Attention Deficit Hyperactivity Disorder. Biological Psychiatry. 2005; 57(11):1263-72. [DOI:10.1016/j.bib opsych.2004.11.019] [PMID]

[4] Biederman J, Spencer T. Attention Deficit Hyperactivity Disorder (ADHD) as a noradrenergic disorder. Biological Psychiatry. 1999; 46(9):1234-42. [DOI:10.1016/S0006-3223(99)00192-4]

[5] Feng L, Wang YF, Cao QJ. A pilot study on effect of methylphenidate on balance function of children with attention deficit hyperactivity disorder. Journal of Peking University, Health Sciences. 2007; 39(3):304-9.

[6] Kim SM, Hyun GJ, Jung TW, Son YD, Cho IH, Kee BS, et al. Balance deficit and brain connectivity in children with Attention Deficit Hyperactivity Disorder. Psychiatry Investig. 2017; 14(4):452-7. [DOI:10.4306/pi.2017.14.4.452] [PMID] [PMCID]

[7] Amini B, Noori M, Janghorban M, Tayebi Sani A. [The comparison of postural control skills under different sensory conditions in DCD children and normal peers (Persian)]. Journal of Modern Rehabilitation. 2016; 9(S3):10-9.

[8] Adi Japha E, Landau YE, Frenkel L, Teicher M, Gross-Tsur V, Shalev RS. ADHD and dysgraphia: Underlying mechanisms. Cortex. 2007; 43(6):700-9. [DOI:10.1016/S0010-9452(08)70499-4]

[9] Williams J, Omizzolo C, Galea MP, Vance A. Motor imagery skills of children with attention deficit hyperactivity disorder and developmental coordination disorder. Human
Movement Science. 2013; 32(1):121-35. [DOI:10.1016/j.hut mov.2012.08.003] [PMID]

[10] Aydinli FE, Çak T, Kirazli MÇ, Çinar BÇ, Pektaş A, Çengel EK, et al. Effects of distractors on upright balance performance in school-aged children with attention deficit hyperactivity disorder, preliminary study. Brazilian Journal of Otorhinolaryngology. 2018; 84(3):280-9. [DOI:10.1016/j.bjorl.2016.10.007]

[11] Pitcher TM, Piek JP, Barrett NC. Timing and force control in boys with attention deficit hyperactivity disorder: Subtype differences and the effect of comorbid developmental coordination disorder. Human Movement Science. 2002; 21(56):919-45. [DOI:10.1016/S0167-9457(02)00167-7]

[12] Shorer Z, Becker B, Jacobi Polishook T, Oddsson L, Melzer I. Postural control among children with and without attention deficit hyperactivity disorder in single and dual conditions. European Journal of Pediatrics. 2012; 171(7):1087-94. [DOI:10.1007/s00431-012-1695-7] [PMID]

[13] Goetz M, Schwabova JP, Hlavka Z, Ptacek R, Surman CB. Dynamic balance in children with Attention Deficit Hyperactivity Disorder and its relationship with cognitive functions and cerebellum. Neuropsychiatric Disease and Treatment. 2017; 13:87380. [DOI:10.2147/NDT.S125169] [PMID] [PMCID]

[14] Tervo RC, Azuma S, Fogas B, Fiechtner H. Children with ADHD and motor dysfunction compared with children with ADHD only. Developmental Medicine and Child Neurology. 2002; 44(6):383-90. [DOI:10.1017/S0012162201002250] [PMID]

[15] Sudha D, Rani MP. Gait classification for ADHD children using modified dual tree complex wavelet transform. Paper presented at: 2017 World Congress on Computing and Communication Technologies (WCCCT). 2-4 February 2017; Tiruchirappalli, India.

[16] Blank R. European Academy of Childhood Disability (EACD): Recommendations on the definition, diagnosis and intervention of developmental coordination disorder (pocket version) German-Swiss interdisciplinary clinical practice guideline S3-standard according to the Association of the Scientific Medical Societies in Germany. Developmental Medicine \& Child Neurology. 2012; 54(11):e1-e7. [DOI:10.1111/ j.1469-8749.2011.04175.x] [PMID]

[17] Bradley JD, Golden CJ. Biological contributions to the presentation and understanding of Attention Deficit Hyperactivity Disorder: A review. Clinical Psychology Review. 2001; 21(6):907-29. [DOI:10.1016/S0272-7358(00)00073-8]

[18] Hyun GJ, Jung TW, Park JH, Kang KD, Kim SM, Son YD, et al. Changes in gait balance and brain connectivity in response to equine-assisted activity and training in children with attention deficit hyperactivity disorder. The Journal of Alternative and Complementary Medicine. 2016; 22(4):28693. [DOI:10.1089/acm.2015.0299] [PMID]

[19] Karatekin C, Markiewicz SW, Siegel MA. A preliminary study of motor problems in children with Attention Deficit Hyperactivity Disorder. Perceptual and Motor Skills. 2003; 97(3_suppl):1267-80. [DOI:10.2466/pms.97.7.1267-1280]

[20] Schoemaker MM, Ketelaars CE, Van Zonneveld M, Minderaa RB, Mulder T. Deficits in motor control processes involved in production of graphic movements of children with Attention Deficit Hyperactivity Disorder. Developmental Medicine and Child Neurology. 2005; 47(6):390-5. [DOI:10.1017/S0012162205000769] [PMID] 
[21] Klimkeit EI, Mattingley JB, Sheppard DM, Lee P, Bradshaw JL. Motor preparation, motor execution, attention, and executive functions in Attention Deficit Hyperactivity Disorder (ADHD). Child Neuropsychology. 2005; 11(2):153-73. [DOI:10.1080/092970490911298] [PMID]

[22] Zang Y, Gu B, Qian Q, Wang Y. Objective measurement of the balance dysfunction in attention deficit hyperactivity disorder children. Chinese Journal of Clinical Rehabilitation. 2002; 6(9):1372-4.

[23] Goulardins JB, Rigoli D, Piek JP, Kane R, Palácio SG, Casella EB, et al. The relationship between motor skills, ADHD symptoms, and childhood body weight. Research in Developmental Disabilities. 2016; 55:279-86. [DOI:10.1016/j. ridd.2016.05.005] [PMID]

[24] Konicarova J, Bob P, Raboch J. Balance deficits and ADHD symptoms in medication-naive school-aged boys. Neuropsychiatric Disease and Treatment . 2014;10:85-8. [PMID] [PMCID]

[25] Mao HY, Kuo LC, Yang AL, Su CT. Balance in children with attention deficit hyperactivity disorder-combined type. Research in Developmental Disabilities. 2014; 35(6):1252-8. [DOI:10.1016/j.ridd.2014.03.020] [PMID]

[26] Swan L, Otani H, Loubert PV, Sheffert SM, Dunbar GL. Improving balance by performing a secondary cognitive task. British Journal of Psychology. 2004; 95(1):31-40. [DOI:10.1348 /000712604322779442] [PMID]

[27] Manicolo O, Grob A, Hagmann-von Arx P. Gait in children with Attention Deficit Hyperactivity Disorder in a dual-task paradigm. Frontiers in Psychology. 2017; 8:34. [DOI:10.3389/ fpsyg.2017.00034] [PMID] [PMCID]

[28] Fayed N, Modrego PJ, Castillo J, Dávila J. Evidence of brain dysfunction in attention deficit-hyperactivity disorder: A controlled study with proton magnetic resonance spectroscopy. Academic Radiology. 2007; 14(9):1029-35. [DOI:10.1016/j. acra.2007.05.017] [PMID]

[29] Ebrahimi M, Mahvashe WA, Haghgoo HA, Pourmohammadrezaye TM, Danaiefard F. The effectiveness of sensorymotor integration with an emphasis on proprioceptive and vestibular senses on the symptoms of Attention Deficit Hyperactivity Disorder (ADHD). Journal of Research in Rehabilitation Sciences. 2013; 9(2):220-31.

[30] Dutra T, Baltar A, Monte-Silva K. Motor cortex excitability in Attention Deficit Hyperactivity Disorder (ADHD): A systematic review and meta-analysis. Research in Developmental Disabilities. 2016; 56:1-9. [DOI:10.1016/j.ridd.2016.01.022] [PMID] 
